\title{
SENTREPRENEURIAL TRAINING AND ORGANIZATIONAL PERFORMANCE: IMPLICATIONS FOR FUTURE Nadeem Khalid $^{1 *}$, Dewan Md. Zahurul Islam ${ }^{2}$, Marwa Refaat Mahmoud Ahmed ${ }^{3}$ \\ ${ }^{1,2}$ KIMEP University, Kazakhstan, ${ }^{3}$ Universiti Utara Malaysia \\ E mail: ${ }^{1 *}$ nadeem.k@ kimep.kz, ${ }^{2}$ mzidewan@googlemail.com, ${ }^{3}$ janna20082002@yahoo.com
}

Article History: Received on $25^{\text {th }}$ February 2019, Revised on $28^{\text {th }}$ March 2019, Published on $25^{\text {th }}$ August 2019

\begin{abstract}
Purpose: The aim of this paper is to enrich our scholarly understanding on the topic of organizational performance. The paper talks about entrepreneurial training and suggests that it can have a significant impact on boosting organizational performance and an organization needs to act concerning to enriching its critical values to ensure they do their best for the business.

Design/Methodology/Approach: This is a conceptual paper, which elaborates on the role and relationship between entrepreneurial training and organizational performance. The paper sheds light on how businesses can further their prosperity, performance and productivity through entrepreneurial training whilst reviewing prominent literature in the area.

Findings: The results of the paper are providing a conclusive understanding to the fact that scholars have reported significant impact of entrepreneurial training on organizational performance. The paper has found that empirical evidence is in line with the prepositions this gives confidence in asserting that all business sectors can responsively work on boosting their organizational performance through entrepreneurial training.
\end{abstract}

Originality/Value: The paper is based on the review of literature on the topics of interest pertaining to the undertaken variables.

Key words: Organizational performance, entrepreneurial training, entrepreneurship, business performance.

\section{INTRODUCTION}

From Schumpeter (1949) there seems to be a great consensus among scholars that the key determinant of an organization's performance either at regional or national entrepreneurship as it provides jobs, offer a range of consumer-goods and services, and it increases the national wealth generally and competitiveness (Zahra, 1993; Yao et al., 2017; Yamaguchi, 2018). Organizational performance lies at the core of every management, as there remains no purpose of existence for a business entity if it is not performing as per the established goals and objectives. Businesses strive to look into diverse prospects to help maintain and/or boost organizational performance (Hickman and Silva, 2018). More recently, there has been a growing discussion amongst the practitioners pertaining to entrepreneurship; underlining its potential in enhancing organizational performance in all areas.

Recent studies on improving organizational performance have underlined the critical significance of entrepreneurial elements (Boso et al., 2013; Suryanto et al., 2018; Ali and Haseeb, 2019). Entrepreneurial orientation according to Miller (1988) is the aspect of creating an environment whereby, new ideas, approaches, products, services and tasks are encouraged, with the aim of leading the organization and boosting competitive position. According to Alegre and Chiva (2013) entrepreneurial orientation creates a conducive environment in the organization, which motivates employees to come up with ideas and creative projects that can make a considerable impact on boosting performance and the achievement of broader objectives.

Hoodbhoy (2009) has stated that a creativity innovative mindset is important for elevating the performance of higher education, especially of the public sector universities that are facing the majority of performance issues. This leads towards understanding the aspect of entrepreneurial training and how it can make a considerable impact on boosting performance of public sector universities in Pakistan. These evidences hint towards the potential significance of entrepreneurial orientation and entrepreneurship factors that boost performance (Pahi et al., 2016; Ahmed et al., 2017; Umrani et al., 2018; Yazdanjoo and Fallahpour, 2018). There lies a major gap as to how public entrepreneurial orientation and entrepreneurial training can enhance the performance. Henceforth, the current paper critically appraised to provide knowledge on the acute importance of entrepreneurial training towards enhancing organizational performance.

\section{ORGANIZATIONAL PERFORMANCE}

From Schumpeter (1949) there seems to be a great consensus among scholars that the key determinant of an organization's performance either at regional or national entrepreneurship as it provides jobs, offer a range of consumer-goods and services, and it increases the national wealth generally and competitiveness. Organizational performance lies at the core of every management, as there remains no purpose of existence for a business entity if it is not performing as per the established goals and objectives. Businesses strive to look into diverse prospects to help maintain and/or boost organizational performance (Hickman and Silva, 2018). More recently, there has been a growing discussion 
amongst the practitioners pertaining to entrepreneurship; underlining its potential in enhancing organizational performance in all areas.

\section{ENTREPRENEURIAL TRAINING}

Kavinda et al. (2013) elaborated that the entrepreneurship training is important and prominent as advanced by many researchers and scholars. Moreover, the impact of training on the performance and development of governmental projects that were highlighted in their national development plans, sessional papers and other policy documents were found to be positive (Ahmed et al., 2017). Entrepreneurship training was found to have had a substantial impact on performance of entrepreneurs. Rosli and Mahmood (2013) found that the employee and employer's entrepreneur training have positive effects on the performance of the firm.

As evident in past studies, the relationship between entrepreneur training and organisational performance is positive (Petridou et al., 2009). Many studies also found that entrepreneur training interact to improve organisational performance and share a direct relationship (Flynn et al., 2003). Researchers saw entrepreneurial training as a tool of reinvention in public sector, thus, continuous training is required for the improvement in the public sector universities.

\section{ENTREPRENEURIAL TRAINING AND ORGANIZATIONAL PERFORMANCE}

Since inception, the Kenya government has developed strategies and promotion programs aimed at improving economy by promoting small-scale enterprises. These programmes are either financial or non-financial. However, the most important of all these is entrepreneurship training as it is through personal development that an enterprise culture can be created. They found personal development has relationship with enterprise culture.

In addition, researchers have found that entrepreneurship training in organization is a growth strategy and effective tool to achieve competitive advantage. Studies on culture and ethics with a focus on entrepreneurship training is an important and useful step for promoting innovation capacity based on entrepreneurial culture because organisational culture and ethical work climate have a very important role in organization. Urbano and Guerrero (2013) classified the basic factors that affect entrepreneurs into two broad categories -economic and social. Codrina (2008) has proposed Entrepreneurship training effects on organization. When workers are trained in certain domain about how to handle different challenges in a successful way, they give out the best they have which ultimately leads towards the high rate of performance of the organization.

Among key guidelines are the content, procedures of selecting appropriate trainers, trainees and the training facilities and methods. Unfortunately, little has been done or said concerning failure of entrepreneurship training program to bring intended impact on the change of attitude and transfer of entrepreneurial skills to target beneficiaries despite the mushrooming of many training institutions, nongovernmental organisations and private consultants (McKenzie and Woodruff, 2013). However, entrepreneurship training was found to have had a substantial impact on performance of entrepreneurs and Medium size enterprises in Kenya.

Entrepreneurial training teaches about the different aspects of entrepreneurship (Buchholz and Rosenthal, 2005). Based on Timmons and Spinelli (2004) who supported the opinion that entrepreneurship can be learnt therefore entrepreneurial trainings must be delivered in Universities so that students must come up with innovative ideas. Rosli and Mahmood (2013) studied on moderating effect of entrepreneurial trainings and found its significant relationship with organizational performance. However, government invests very low in this domain. An entrepreneur is regarded as inventive individual though skills must be improved through training (Bharadwai and Menon, 2000). That is why public universities should play their part to develop entrepreneurial individuals. Public or non-profit making organizations always try to adjust with high fringe benefits and low costs so entrepreneurial training must be there to help these organizations in achieving their goals.

Researchers indicated the significance of entrepreneurship training as public or government sector is looking for goals and business methods with innovative ideas to improve their performance and efficiency. Furthermore, education can play a vital role for these developments (Kearney et al., 2009; Yoke et al., 2018; Zafarullah, 2018; Zheng, 2018). This study will look at the practical implementation of entrepreneurial training in public sector universities of Pakistan and its impact on performance, as the studies are non-existent in this context. Therefore, as suggested by previous literature, this variable is of much importance.

Rosli and Mahmood (2013) stated that the effect of HRM practices and entrepreneurial training on the relationship between innovation and firm performance are non-existent. Two hundred eighty-four samples were obtained from SMEs in Malaysia. This study found that the employee and employer training interacted with innovation and significantly influenced SMEs performance. Theoretically, greater performance of SMEs is not merely explained by how much they put their effort in innovation, but also how much they invest in employee and employer training. This also reminds the SMEs that innovation and training of both employee and entrepreneur must go hand in hand, so that their performance can be enhanced. 


\section{CONCLUSION}

The current review based paper aimed to outline the importance of entrepreneurial training towards furthering organizational performance. The paper aims to act as a guideline for researchers and academicians to facilitate corporate world through scholarly work in this regard. The paper provides healthy appraisal to make convinced that entrepreneurial training has a major role in maximizing organizational performance and an organization needs to act with regards to enriching its critical values to ensure they do their best for the business.

\section{REFERENCES}

1. Ahmed, U., N. Khalid, A. Ammar and M.H. Shah, 2017. Assessing moderation of employee engagement on the relationship between work discretion, job clarity and business performance in the banking sector of Pakistan. Asian Economic and Financial Review, 7(12): 1197.https://doi.org/10.18488/journal.aefr.2017.712.1197.1210

2. Ahmed, U., W.A. Umrani, M.H. Pahi and S.M.M. Shah, 2017. Engaging PhD students: Investigating the role of supervisor support and psychological capital in a mediated model. Iranian Journal of Management Studies, 10(2): 283-306.

3. Alegre, J. and R. Chiva, 2013. Linking entrepreneurial orientation and firm performance: The role of organizational learning capability and innovation performance. Journal of Small Business Management, 51(4): 491-507.https://doi.org/10.1111/jsbm.12005

4. Ali, A. and M. Haseeb, 2019. Radio frequency identification (RFID) technology as a strategic tool towards higher performance of supply chain operations in textile and apparel industry of Malaysia. Uncertain Supply Chain Management, 7(2): 215-226.https://doi.org/10.5267/j.uscm.2018.10.004

5. Bharadwaj, S. and A. Menon, 2000. Making innovation happen in organisations: Individual creativity mechanisms, organisational creativity mechanism or both? Journal of Production and Innovation Management, 17: 424-434.https://doi.org/10.1016/S0737-6782(00)00057-6

6. Boso, N., V.M. Story and J.W. Cadogan, 2013. Entrepreneurial orientation, market orientation, network ties, and performance: a Study of entrepreneurial firms in a developing economy. Journal of Business Venturing, 28(6): 708-727.https://doi.org/10.1016/j.jbusvent.2013.04.001

7. Buchholz, R.A. and S.B. Rosenthal, 2005. The spirit of entrepreneurship and the qualities of moral decision making: Toward a unifying framework. Journal of Business Ethics, 60(3): 307-315. https://doi.org/10.1007/s10551-005-0137-0

8. Codrina, C.L., 2008. A study of human resource management practices in romanian private companies. Annals of the University of Oradea, Economic Science Series, 17(4).

9. Flynn, M., L. Dooley, D. O'sullivan and K. Cormican, 2003. Idea management for organisational innovation. International Journal of Innovation Management, 7(4): 417-442.https://doi.org/10.1142/S1363919603000878

10. Hickman, C.R. and M.A. Silva, 2018. Creating excellence: Managing corporate culture, strategy, and change in the new age. Routledge.https://doi.org/10.4324/9781351065306

11. Hoodbhoy, P., 2009. Pakistan's higher education system-what went wrong and how to fix it. The Pakistan Development Review, 48(4): 581-594.https://doi.org/10.30541/v48i4IIpp.581-594

12. Kavinda, L., R. Maganjo and P.P. Kithae, 2013. Impact of entrepreneurship training on performance of micro and small enterprises (Mses) in Kenya: A case study of Embu Municipality. European centre for Research Training and Development. Available from http://ir-library.ku.ac.ke/handle/123456789/8077.

13. Kearney, C., R.D. Hisrich and F. Roche, 2009. Public and private sector entrepreneurship: Similarities, differences or a combination? Journal of Small Business and Enterprise Development, 16(1): 26-46. https://doi.org/10.1108/14626000910932863

14. McKenzie, D. and C. Woodruff, 2013. What are we learning from business training and entrepreneurship evaluations around the developing world? : The World Bank Research Observer, lkt007. https://doi.org/10.1596/1813-9450-6202

15. Miller, D., 1988. Relating porter's business strategies to environment and structure: Analysis and performance implications. Academy of Management Journal, 31(2): 280-308.https://doi.org/10.2307/256549

16. Pahi, M.H., S.M.M. Shah, U. Ahmed and W.A. Umrani, 2016. Investigating the issue of nurse job satisfaction: Role of esprit de corps, task significance, self-efficacy and resilience: A case study. International Journal of Academic Research in Business and Social Sciences, 6(4): 339-335. https://doi.org/10.6007/IJARBSS/v6-i4/2112

17. Petridou, E., A. Sarri and L.P. Kyrgidou, 2009. Entrepreneurship education in higher educational institutions: The gender dimension. Gender in Management: An International Journal, 24(4): 286-309. https://doi.org/10.1108/17542410910961569

18. Rosli, M.M. and R. Mahmood, 2013. Moderating effects of human resource management practices and entrepreneur training on innovation and small-medium firm performance. Journal of Management and Strategy, 
4(2): 60-69.https://doi.org/10.5430/jms.v4n2p60

19. Schumpeter, J.A., 1949. Science and ideology. 1994: 224-238.

20. Suryanto, T., M. Haseeb and N.H. Hartani, 2018. The correlates of developing green supply chain management practices: Firms level analysis in Malaysia. International Journal of Supply Chain Management, 7(5): 316.

21. Timmons, J. and S. Spinelli, 2004. New venture strategies: Entrepreneurship for the 21st century. Burr Ridge, IL: Irwin-McGraw-Hill.

22. Umrani, W.A., K.M. Kura and U. Ahmed, 2018. Corporate entrepreneurship and business performance: The moderating role of organizational culture in selected banks in Pakistan. PSU Research Review, 2(1): 59-80. https://doi.org/10.1108/PRR-12-2016-0011

23. Urbano, D. and M. Guerrero, 2013. Entrepreneurial universities socioeconomic impacts of academic entrepreneurship in a European region. Economic Development Quarterly, 27(1): 40-55. https://doi.org/10.1177/0891242412471973

24. Yamaguchi, M., 2018. Are foreign banks in china homogenous? Classification of their business patterns. Journal of Accounting, Business and Finance Research, 3(1): 10-17.https://doi.org/10.20448/2002.31.10.17

25. Yao, T.K., O. Fouché, K.E. Kouadio and M.-S. Oga, 2017. Discontinuous nature of phreatic aquifers in granitic rocks at watershed scale: A stratiform model from perennial streams and well data. Asian Review of Environmental and Earth Sciences, 4(1): 20-27.https://doi.org/10.20448/journal.506.2017.41.20.27

26. Yazdanjoo, S. and H. Fallahpour, 2018. A study on the correlation between creative thinking of iranian efl learners and using metaphor in descriptive writing tasks. International Journal of English Language and Literature Studies, 7(2): 32-44.https://doi.org/10.18488/journal.23.2018.72.32.44

27. Yoke, C.C., Y.W. Mun, L.M. Peng and U.L. Yean, 2018. Purchase intention of residential property in greater kuala lumpur, malaysia. International Journal of Asian Social Science, 8(8): 580-590. https://doi.org/10.18488/journal.1.2018.88.580.590

28. Zafarullah, M., 2018. Impact of vat on uae economy. Asian Development Policy Review, 6(1): 41-49. https://doi.org/10.18488/journal.107.2018.61.41.49

29. Zahra, S.A., 1993. Environment, corporate entrepreneurship, and financial performance: A taxonomic approach. Journal of Business Venturing, 8(4): 319-340.https://doi.org/10.1016/0883-9026(93)90003-N

30. Zheng, J., 2018. The incorporation of subject knowledge in teaching scientific translation. International Journal of English Language and Literature Studies, 7(2): 45-49.https://doi.org/10.18488/journal.23.2018.72.45.49 